\title{
A journey through the history of Neurogenetics
}

\author{
Uma jornada pela história da Neurogenética \\ Thiago Yoshinaga Tonholo SILVA', José Luiz PEDROSO', Marcondes Cavalcante FRANÇA JUNIOR², \\ Orlando Graziani Povoas BARSOTTINI
}

\begin{abstract}
Since the late 19th century, when several inherited neurological disorders were described, the close relationship between Neurology and heredity were well documented by several authors in a pre-genetic era. The term Neurogenetics came to integrate two large sciences and clinical practices: Neurology and Genetics. Neurogenetics is the emerging field that studies the correlation between genetic code and the development and function of the nervous system, including behavioral traits, personality and neurological diseases. In this historical note, a timeline shows the main events and contributors since the first reports of neurogenetic diseases until the current days. In the recent years, neurologists are experiencing much broader use of new genetic diagnosis techniques in clinical practice. Thus, new challenges are arising in diagnostic approach, ethical considerations, and therapeutic options. This article aims to summarize the main historical hallmarks of Neurogenetics, from the pre-DNA era to the present, and the future directions of the field.
\end{abstract}

Keywords: Genetic Diseases, Inborn; History; Neurology; Genetics.

\section{RESUMO}

Desde o final do século XIX, quando diversas doenças neurológicas hereditárias foram descritas, a associação entre neurologia e hereditariedade foi bem documentada por vários autores na era pré-genética. O termo Neurogenética integra dois campos da ciência e da prática clínica: Neurologia e Genética. A Neurogenética é o campo que estuda a correlação entre o código genético e o desenvolvimento e a função do sistema nervoso, incluindo comportamento, personalidade e doenças neurológicas. Nesta nota histórica, a linha do tempo mostra os principais eventos e pesquisadores desde os primeiros relatos de doenças neurogenéticas até os dias atuais. Recentemente, neurologistas estão se deparando com maior uso de técnicas diagnósticas genéticas na prática clínica; portanto, novos desafios surgem na abordagem diagnóstica, nas considerações éticas e na terapêutica. Este artigo almeja resumir os principais marcos históricos da Neurogenética, desde a era pré-DNA até o presente, e os caminhos futuros desse campo de conhecimento.

Palavras-chave: Doenças Genéticas Inatas; História; Neurologia; Genética.

Since the birth of modern Neurology in the late 19th century, many physicians noticed the importance of family history in the diagnostic approach of neurological disorders. At that time, studies in the Genetics area tried to better understand the mechanisms involved in inherited diseases.

The term Neurogenetics integrates two areas: Neurology and Genetics. It formally started in mid-1960s when Seymour Benzer developed experiments with Drosophila, intending to prove that animal behaviors could be directed by single gene mutations (Figure 1). Benzer's research also became the cornerstone to the study of neurological diseases in humans, particularly, neurodegenerative disorders ${ }^{1,2}$.

This article aims to summarize the major historical hallmarks in the field of neurogenetics, from the pre-DNA era to the present, and the future directions of the field.

\section{THE FIRST NEUROGENETIC DISEASES}

Gregor Mendel, the "father of modern Genetics", is acknowledged for his experiments with pea plants

\footnotetext{
1 Universidade Federal de São Paulo, Departamento de Neurologia, São Paulo SP, Brazil.

¿Universidade de Campinas, Departamento de Neurologia, Campinas SP, Brazil.

TYTS (iD) https://orcid.org/0000-0002-7185-8309;JLP (D) https://orcid.org/0000-0002-1672-8894; MCFJ (D) https://orcid.org/0000-0003-0898-2419; OGPB (iD) https://orcid.org/0000-0002-0107-0831

Correspondence: José Luiz Pedroso; Email: jlpedroso.neuro@gmail.com.

Conflict of interest: There is no conflict of interest to declare.
}

Authors' contributions: TYTS, JLP, MCFJ, OGPB: conception, organization, and execution of the project. Writing of the first draft and review and critique of the manuscript.

Received on December 08, 2020; Received in its final form on March 14, 2021; Accepted on March $28,2021$. 


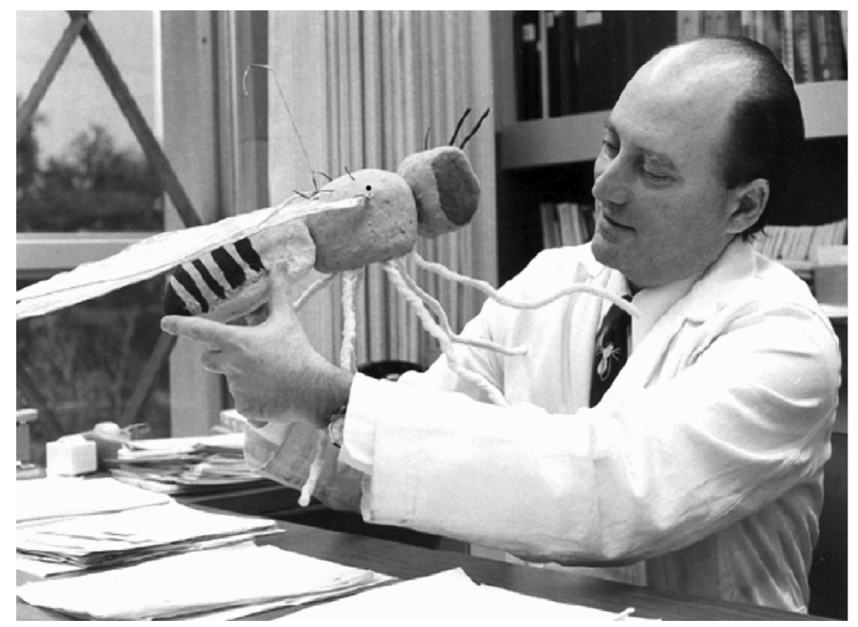

Source: Seymour Benzer 1921-2007 The Man Who Took Us from Genes to Behaviour. Available at: https://doi.org/10.1371/journal.pbio.0060041.g001

Figure 1. Seymour Benzer, considered the father of

Neurogenetics, in his office at Caltech in 1974 with a big model of Drosophila.

hybridization, published in 1866, in which he synthetized the laws of inheritance. His work, though, remained obscure until 1900, when it was rediscovered ${ }^{3}$. However, even before Mendel, physicians had already recognized inherited patterns of neurological diseases.

In 1863, Nikolaus Friedreich described a hereditary juvenile-onset ataxia with sensory loss, cardiomyopathy, scoliosis and pes cavus. More than a century later the genetic basis of Friedreich`s ataxia was described: guanine-adenosine-adenosine (GAA) trinucleotide repeat ${ }^{4,5}$. In 1872, George Huntington wrote the essay "On Chorea", where he described the hereditary nature, neuropsychiatric symptoms and adultonset. Huntington's disease is caused by expansion in trinucleotide cytosine-adenosine-guanine (CAG) repeat ${ }^{6,7}$.

In 1880, the first depiction of hereditary spastic paraplegia was published by Ernst Adolf Gustav Gottfried von Strümpell. Maurice Lorrain, in 1888, contributed with anatomical description. Since then, more than 80 loci have been related to hereditary spastic paraplegia ${ }^{8}$. In 1886 , the hereditary sensorimotor neuropathy was described independently by two groups: in France, Jean Martin Charcot and Pierre Marie published a progressive muscular atrophy, with child and juvenile onset, distal lower limb atrophy and pes cavus. Later, Henry Tooth reported five patients with progressive muscular atrophy'.

Pierre Marie, in 1893, reviewed a series of ataxia with adult onset, oculomotor abnormalities and autosomal dominant inheritance. Later, Joseph Jules Dejerine and André-Thomas suggested the term olivopontocerebellar atrophy (OPCA) to describe this disease. Through the 20th century, several disorders were recognized under the broad phenotype of Marie's ataxia, most of them encompassed in the group of spinocerebellar ataxias (SCA). Currently, more than 40 gene loci causing SCAs have been described ${ }^{10,11,12}$.

\section{DNA DISCOVERY AND MOVING ON}

In the 1910s, Thomas Morgan proved that genes resided in certain locations of chromosomes. In 1944, Oswald Avery, Colin MacLeod and Maclyn McCarty concluded that DNA held the genetic information. In 1953, James Watson and Francis Crick demonstrated the DNA structure ${ }^{13}$. In the late 1950s, Seymour Benzer showed that a mutation could occur in multiple sites within the genetic code, originating the notion of "point mutation"14. In the 1970s, Fredrick Sanger developed the first widely used method of DNA sequencing relying on nucleotide-specific chain-termination inhibitors ${ }^{13}$.

By 1980s, advances in molecular biology techniques, especially reverse genetics and recombinant DNA, allowed the identification of causal association between DNA variants and diseases through linkage analysis: the knowledge that DNA sequences that are closer in the chromosome tend to segregate together during meiosis have allowed the construction of linkage maps, using recombinant DNA probes, which ultimately led to identification the locus of Huntington's disease in 1983, and the discovery of the gene for Duchene muscular dystrophy in 1987 without prior knowledge of the defective protein ${ }^{15}$.

The 1990s were marked by the discovery of di-, tri and tetranucleotide repeats (microsatellites) which are highly polymorphic among healthy people and the ease of genotyping these repeats with polymerase chain reaction (PCR). These innovations led to the discovery of several specific genes related to classical neurological diseases, such as Charcot-Marie-Tooth's, amyotrophic lateral sclerosis, Parkinson's, Alzheimer's, spinocerebellar ataxias and fragile $\mathrm{X}$ syndrome ${ }^{16}$.

More recently, several names participated on extremely relevant works around neurogenetics. Of note, Anita Elizabeth Harding participated on the discovery of the mitochondrial DNA mutation in human disease and the concept of tissue heteroplasmy of mutant mitochondrial DNA.

In the 2000s, the integration of phenotypic mapping and sequencing data with new computational resources enabled the recognition of a larger number of hereditary disorders. In this same decade, the Human Genome Project (19902003) determined the entire sequence of base pairs that make up human DNA. By 2010, with the next-generation sequencing (NGS) development, whole genome sequence could be analyzed in few weeks ${ }^{17}$. Figure 2 is a timeline that shows the main events and contributors since the first reports of neurogenetic diseases till the current days.

In Brazil, many scientists and clinicians have participated on the description of neurogenetic diseases during the last decades. Some Brazilian institutions, such as the Centro de Estudos do Genoma Humano e Células-Tronco from the Universidade de São Paulo, have played an important role in the studies of neurogenetic diseases. 


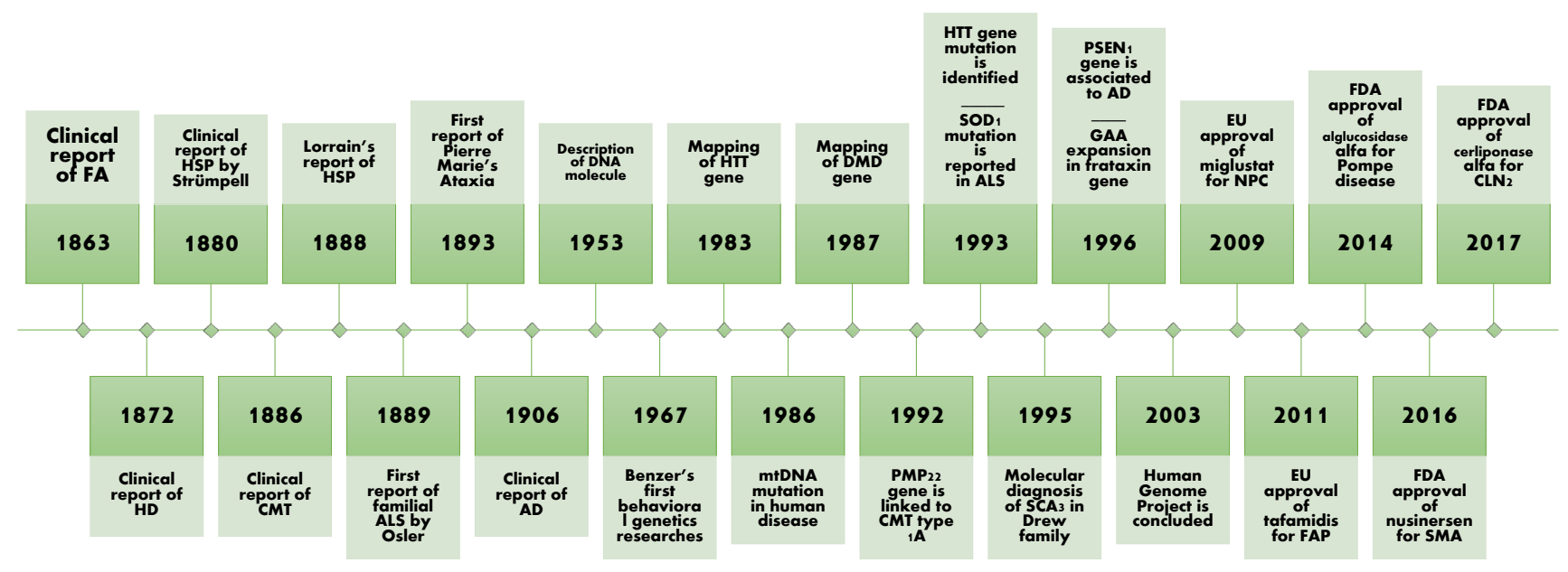

FA: Friedreich ataxia; HD: Huntington disease; HSP: hereditary spastic paraplegia; CMT:Charcot-Marie-Tooth; ALS: amyotrophic lateral sclerosis;AD: Alzheimer disease; DMD: Duchenne muscular dystrophy; EU: European Union; NPC: Niemann-Pick type C disease; FDA: Food and Drug Administration; SMA: spinal muscular atrophy; FAP: familial amyloid polyneuropathy; CLN2: ceroid neuronal lipofuscinosis type 2.

Figure 2. Timeline with the main events and contributors since the first reports of neurogenetic diseases until the current days.

\section{THE ERA OF EXOME SEQUENCING}

The NGS, released in the mid-2000s, offered an improvement in processing the genetic investigation. Through the selection of regions of interest, whole exome sequencing (WES) allowed the successful identification of several monogenic diseases ${ }^{18}$. WES and whole genome sequencing (WGS) allowed the accurate identification of single nucleotide variants and small insertions or deletions (InDels). For larger InDels, copy-number variation and genomic rearrangements, microarray, and MLPA techniques are more accurate ${ }^{19}$.

\section{FUTURE DIRECTIONS: WHAT IS NEXT?}

With NGS development, a new modus operandi is arising in diagnostic approach: for instance, WES turns out to be a better diagnostic tool for leukodystrophies diagnostic assessment, allowing more precise, faster, and less costly approach when compared to the traditional biochemical laboratorial investigation. This rapid evolution of technology will demand a continuous update in data interpretation of clinical and NGS information, and, consequentially, genetic counseling ${ }^{19}$.
Furthermore, there are ethical dilemmas to point out: genetic testing in asymptomatic individuals and the psychological side effects of the diagnosis (e.g., HD diagnosis in pre-symptomatic patient), confidentiality of genetic information, genetic testing in children, whose autonomy is delegated to the parents, and prenatal testing of embryos are issues that need to be carefully considered in our daily practice, as the cost of genetic test drop and more people can perform the exams.

For a long time, symptomatic treatment was the only option for neurogenetic disorders. Recently, the scenario has been changing as specific disease-modifying drugs for neurogenetic conditions have been approved. Several biochemical therapies were developed for inborn errors of metabolism (e.g., miglustat to treat Niemann-Pick type C, and migalastat for Fabry disease); antisense oligonucleotides (ASO) and gene therapy have an increasing importance, since clinical trials to treat polyglutamine disorders, such as HD and SCA 2, are being held, and antisense therapy for Duchenne muscular dystrophy (DMD) has been aproved $^{18}$. Moreover, CRISPR-cas9 genome editing technology has emerged as a perspective for the treatment of neurogenetic disorders ${ }^{20}$.

\section{References}

1. Bonini NM. A tribute to Seymour Benzer, 1921-2007. Genetics. 2008 Nov;180(3):1265-73. https://doi.org/10.1534/genetics.104.97782

2. Greenspan RJ. Seymour Benzer (1921-2007). Curr Biol. 2008 Feb;18(3):R106-10. https://doi.org/10.1016/j.cub.2007.12.039

3. Zhang $H$, Chen W, Sun K. Mendelism: new insights from Gregor Mendel's lectures in Brno. Genetics. 2017 Sep;207(1):1-8. https://doi. org/10.1534/genetics.117.201434.
4. Schulz JB, Pandolfo M. 150 years of Friedreich Ataxia: from its discovery to therapy.J Neurochem. 2013 Aug;126 Suppl 1:1-3. https:// doi.org/10.1111/jnc.12327

5. Abrahão A, Pedroso JL, Braga-Neto P, Bor-Seng-Shu E, de Carvalho Aguiar P, Barsottini OG. Milestones in Friedreich ataxia: more than a century and still learning. Neurogenetics. $2015 \mathrm{Jul} ; 16(3): 151-60$. https://doi.org/10.1007/s10048-015-0439-z 
6. Testa CM, Jankovic J. Huntington disease: A quarter century of progress since the gene discovery. J Neurol Sci. 2019 Jan;396:52-68. https://doi.org/10.1016/j.jns.2018.09.022

7. Wexler A, Wild EJ, Tabrizi SJ. George Huntington: a legacy of inquiry, empathy and hope. Brain. 2016 Aug;139(Pt 8):2326-33. https://doi. org/10.1093/brain/aww165

8. Faber I, Pereira ER, Martinez ARM, França Jr M, Teive HAG. Hereditary spastic paraplegia from 1880 to 2017: an historical review. Arq Neuro-Psiquiatr. 2017 Nov;75(11):813-8 https://doi. org/10.1590/0004-282X20170160

9. Kazamel M, Boes CJ. Charcot Marie Tooth disease (CMT): historical perspectives and evolution. J Neurol. 2015 Apr;262(4):801-5. https:// doi.org/10.1007/s00415-014-7490-9

10. Bird TD. Hereditary Ataxia Overview. In: Adam MP, Ardinger HH, Pagon RA, et al., editors. GeneReviews ${ }^{\circledR}$. Seattle (WA): University of Washington, Seattle;1993-2021. p. 1-39.

11. Meira AT, Pedroso JL, Boller F, Franklin GL, Barsottini OGP, Teive HAG. Reconstructing the History of Machado-Joseph Disease. Eur Neurol. 2020 May;83(1):1-6. https://doi.org/10.1159/000507191

12. Teive HAG, Arruda WO. A família Drew de Walworth: um século após a avaliação inicial finalmente o diagnóstico doença de MachadoJoseph. Arq Neuro-Psiquiatr. 2004 Mar;62(1):177-80. https://doi. org/10.1590/S0004-282X2004000100034

13. Gayon J. De Mendel à l'épigénétique : histoire de la génétique. C R Biol. 2016 Jul-Aug;339(7-8):225-30. https://doi.org/10.1016/j.crvi.2016.05.009
14. Hargittai I, Hargittai M. Candid science VI [electronic resource]: more conversations with famous scientists. London: Imperial College Press, 2006.

15. Mathis S, Tazir M, Magy L, Duval F, Le Masson G, Duchesne M, et al. History and current difficulties in classifying inherited myopathies and muscular dystrophies. J Neurol Sci. 2018 Jan;384:50-4. https:// doi.org/10.1016/j.jns.2017.10.051

16. Durmaz AA, Karaca E, Demkow U, Toruner G, Schoumans J, Cogulu O. Evolution of genetic techniques: Past, present, and beyond. Biomed Res Int. 2015 Mar;2015:461524. https://doi. org/10.1155/2015/461524

17. Tandon PN. The decade of the brain: a brief review. Neurol India. 2000 Sep;48(3):199-207.

18. Scoles DR, Pulst SM. Oligonucleotide therapeutics in neurodegenerative diseases. RNA Biol. 2018;15(6):707-14. https:// doi.org/10.1080/15476286.2018.1454812

19. Petersen BS, Fredrich B, Hoeppner MP, Ellinghaus D, Franke A. Opportunities and challenges of whole-genome and -exome sequencing. BMC Genet. 2017;18:1-13. https://doi.org/10.1186/ s12863-017-0479-5

20. Madigan NN, Staff NP, Windebank AJ, Benarroch EE. Genome editing technologies and their potential to treat neurologic disease. Neurology. 2017 Oct;89(16):1739-48. https://doi.org/10.1212/ WNL.0000000000004558 